\title{
Fate of superfluous sperm products after vasectomy and in the normal male tract of the mouse
}

\author{
C. L. R. Barratt* and Jack Cohen \\ Department of Zoology \& Comparative Physiology, University of Birmingham, \\ Birmingham B15 2TT, U.K.
}

\begin{abstract}
Summary. The progression of ${ }^{3} \mathrm{H}$-labelled spermatozoa (thymidine or arginine) was followed through the tracts of unilaterally vasectomized, bilaterally vasectomized, oligozoospermic $\left(t^{6} / t^{w 5}\right)$ and normal mice; the regional lymph nodes were also investigated. The same rate of sperm production and transport was found in normal and in vasectomized tracts, down to the corpus epididymidis; there was some delay in spermatozoa entering the cauda in the vasectomized tracts. In the mouse, therefore, vasectomy does not affect the rates of sperm production or transport until just before the blockage in the swollen cauda epididymidis. Radioactivity appeared in the caudal and "paraaortic' lymph nodes as the radioactive spermatozoa passed from the corpus, showing that this is one route of disposal of spermatozoa, or of sperm products, after vasectomy.

Naturally oligozoospermic and normal mice gave similar results; again the caudal, iliac and renal lymph nodes received radioactive spermatozoa/sperm products. Some loss of (by definition) superfluous spermatozoa in the normal male tract therefore occurs naturally by this route, and we suggest that vasectomy further exploits this physiological pathway. This would account for the finding that many males do not make antisperm antibodies after vasectomy, just as normal males do not, even though their lymph nodes normally receive spermatozoa/sperm products.
\end{abstract}

\section{Introduction}

Many authors have used radiolabelled spermatozoa to show the duration of normal epididymal transport (Orgebin-Crist, 1965; Fulka, Kopecny \& Koefoed-Johnson, 1971; Dadoune \& Alfonsi, 1984), but the passage of labelled spermatozoa in the tracts of vasectomized animals has not been investigated. Vasectomy is a common clinical practice with few unwanted sequelae. Spermatogenesis continues after vasectomy (Lepow \& Crozier, 1979; Howards, Flickinger, Noller \& Panko, 1979; Flickinger, 1981; Ball \& Setchell, 1983), but there has been little investigation of the rate of spermatogenesis or of sperm transport after vasectomy.

The mechanisms of sperm disposal after vasectomy are still uncertain. Ball, Naylor \& Mitchinson (1982) reported large numbers of spermatozoa (as sperm heads) in the para-aortic lymph nodes of a vasectomized man, and referred to similar but unpublished observations in mice. Ball \& Setchell (1983), using unilaterally vasectomized rams and boars, found whole spermatozoa in the regional lymph nodes and vessels on the vasectomized side, and in one animal on the normal side. Even during normal spermatogenesis and passage through the male tract there is considerable cell loss (Cooper \& Hamilton, 1977; Johnson, Petty \& Neaves, 1983); more loss occurs in some oligozoospermic males (Tucker, 1980; Hillman \& Nadijcka, 1980). Whatever disposal mechanisms occur

\footnotetext{
* Present address: Department of Obstetrics and Gynaecology, University of Sheffield, Jessop Hospital for Women, Sheffield S3 7RE, U.K.
} 
naturally, e.g. phagocytosis (Bernard, 1984) or lysis of spermatozoa (Jean et al., 1979), it is important to discover whether vasectomy exploits this physiological disposal route or whether it initiates new mechanisms usually considered as pathology, such as granulomata (Lepow \& Crozier, 1979).

We have therefore injected tritiated thymidine or arginine into both testes of normal, unilaterally vasectomized, bilaterally vasectomized or oligozoospermic mice and located the radiolabel.

\section{Materials and Methods}

Animals. Mice used were mostly Strong A (Birmingham strain YP). The few male, tailed crosses, $t^{6} / t^{w 5}$ of C57 carrying $T / t^{6}$ and CBA carrying $T / t^{w 5}$, were accumulated over some months and used as oligozoospermic mice (Tucker, 1980). All mice were maintained at $19-21^{\circ} \mathrm{C} 50 \%$ humidity, under a lighting regimen of $12 \mathrm{~h}$ light. Mice were anaesthetized by intraperitoneal injection of a metomidate (Crown Chemicals Ltd, Lamberhurst, Kent) and fentanyl (Janssen Pharmaceutical Ltd, Oxfordshire) mixture $(4.0 \mathrm{ml}(0.04 \mathrm{mg})$ metomidate, $0.8 \mathrm{ml}(0.20 \mathrm{~g})$ fentanyl, $11.2 \mathrm{ml}$ distilled water). The dose was $0.125 \mathrm{ml} / 10 \mathrm{~g}$ body weight. In the interests of animal economy, only one mouse per day was killed (by cervical dislocation) for each experiment.

Vasectomy. Vasectomy was performed on the YP mice when they were 10 weeks old by the method of Lipshultz \& Benson (1980). For unilateral vasectomies, the left side of each mouse was vasectomized completely, but on the right side the vas was sham-operated only.

Radiolabel injections. At 2 weeks after vasectomy, the mice were injected with radiolabel: $10 \mu \mathrm{Ci}$ of $\left[6-{ }^{3} \mathrm{H}\right]$ thymidine (sp. act. $23 \mathrm{Ci} / \mathrm{mmol}$ : Amersham Radiochemicals, Amersham, U.K.) or $10 \mu \mathrm{Ci}$ L- $\left[5(\mathrm{n})-{ }^{3} \mathrm{H}\right]$ arginine monohydrochloride (sp. act. $18 \mathrm{Ci} / \mathrm{mmol}$ : Amersham Radiochemicals) were injected into each testis of each mouse. Injections, while the mice were anaesthetized, were made through a small slit in the scrotal sac, using a 30-gauge needle. The day of injection was Day 0.

The experiments. Four successive experiments were performed (see Table 1). In Exp. $1\left[{ }^{3} \mathrm{H}\right]$ thymidine and unilaterally vasectomized mice were used to trace sperm transport in the tracts. In Exp. 2 a more detailed comparison was performed with $\left[{ }^{3} \mathrm{H}\right]$ arginine, examining lymph nodes as well as the male tracts for radioactivity. Then, because the use of 1 mouse for each day permitted satisfactory tracing of sperm disposal, a definitive study (Exp. 3) was undertaken with $\left[{ }^{3} \mathrm{H}\right]$ arginine to test oligozoospermic and normal mice similarly. Finally (Exp. 4), $\left[{ }^{3} \mathrm{H}\right]$ thymidine was used to give a sharper definition of the radioactive sperm cohort. As a check to see that scintillation counting was really showing radioactive spermatozoa, sections or smears of the tract were autoradiographed (Rogers, 1979). Tritium-labelled thymidine is incorporated into preleptotene spermatocytes and spermatogonia; therefore, spermatozoa containing DNA labelled with $\left[{ }^{3} \mathrm{H}\right]$ thymidine were expected in the caput epididymidis about 26 days after injection (Clermont \& Trott, 1969). Tritium-labelled arginine is incorporated into spermatid stages 11-15 undergoing nuclear condensation, to form arginine-rich basic proteins (Kopecny \& Pavlok, 1975); therefore, [ $\left.{ }^{3} \mathrm{H}\right]$ arginine-labelled spermatozoa were expected to appear in the caput epididymidis about 2-3 days after injection.

Experimental methodology. In Exps 1 and 2 the complete reproductive tract on each side was removed, cleaned of fat and separated into testis, caput, corpus and cauda epididymidis and vas deferens, each of which was then weighed. Small portions of each organ $(\sim 3 \mathrm{mg})$ were placed in Bouin's fixative for future autoradiographic processing (Rogers, 1979), and the DNA/protein fraction of the remaining portion was extracted by the method described by Munro \& Fleck (1966). The radioactivity in this fraction, and of the washings (supernatants) during the extraction procedure, was estimated by liquid scintillation counting. A $0.5 \mathrm{ml}$ aliquant of each sample was placed in a scintillation vial with $9 \mathrm{ml}$ Fisofluor 1 (Fisons Ltd, Loughborough, U.K.), left in the dark for $24 \mathrm{~h}$ and then the $\mathrm{pH}$ was adjusted to neutral by adding 5 drops of $4 \mathrm{~N}-\mathrm{HNO}_{3}$. Counting was carried out on a Philips PW470 liquid scintillation counter using the external standards 
Table 1. Details of Exps 1-4

\begin{tabular}{|c|c|c|c|c|c|c|c|}
\hline Exp. & $\begin{array}{l}\text { Radio-label } \\
\text { used }\end{array}$ & $\begin{array}{l}\text { Type } \\
\text { of } \\
\text { mice* }\end{array}$ & $\begin{array}{l}\text { Sampling } \\
\text { days after } \\
\text { injection }\end{array}$ & $\begin{array}{l}\text { No. } \\
\text { of } \\
\text { mice }\end{array}$ & $\begin{array}{c}\text { Tissue } \\
\text { examined }\end{array}$ & $\begin{array}{l}\text { Method to } \\
\text { detect } \\
\text { radioactivity }\end{array}$ & $\begin{array}{l}\text { Figures } \\
\text { showing } \\
\text { results }\end{array}$ \\
\hline 1 & {$\left[{ }^{3} \mathrm{H}\right]$ Thymidine } & u.v. & $\begin{array}{c}22,23,24 \\
25,26 \\
26 \cdot 5,27\end{array}$ & 7 & $\begin{array}{l}\text { † Contralateral and } \\
\text { ipsilateral testis, } \\
\text { caput, cauda and vas }\end{array}$ & $\begin{array}{l}\text { Scintillation } \\
\text { counting and } \\
\text { autoradiography }\end{array}$ & 1 \\
\hline 2 & {$\left[{ }^{3} \mathrm{H}\right]$ Arginine } & u.v. & 1-13 (incl.) & 13 & $\begin{array}{l}\text { † Contralateral and } \\
\text { ipsilateral testis, } \\
\text { caput, corpus, cauda } \\
\text { and vas; } \\
\text { caudal iliac, renal } \\
\text { and inguinal lymph } \\
\text { nodes }\end{array}$ & $\begin{array}{l}\begin{array}{l}\text { Scintillation } \\
\text { counting and } \\
\text { autoradiography }\end{array} \\
\text { Scintillation } \\
\text { counting }\end{array}$ & 2 \\
\hline 3 & {$\left[{ }^{3} \mathrm{H}\right]$ Arginine } & $\begin{array}{c}\mathrm{n} \\
\text { u.v. } \\
\mathrm{o}\end{array}$ & 1 and $7-11$ & $\begin{array}{l}6 \\
6 \\
6\end{array}$ & $\begin{array}{l}\text { + Caput epidiymidis } \\
\text { and caudal lymph } \\
\text { nodes }\end{array}$ & $\begin{array}{l}\text { Scintillation } \\
\text { counting }\end{array}$ & 4 \\
\hline 4 & {$\left[{ }^{3} \mathrm{H}\right]$ Thymidine } & $\begin{array}{l}\mathrm{n} \\
\text { u.v. } \\
\text { b.v. } \\
\text { o }\end{array}$ & $\begin{array}{l}22-33 \text { (incl.) } \\
22-33 \text { (incl.) } \\
22-33 \text { (incl.) } \\
22-31 \text { (incl.) }\end{array}$ & $\begin{array}{l}13 \\
13 \\
13 \\
11\end{array}$ & $\begin{array}{l}\text { † Spermatozoa } \\
\text { isolated from tract } \\
\text { (caput, corpus, } \\
\text { cauda, vas) and } \\
\text { solubilized; } \\
\text { caudal, iliac and } \\
\text { renal lymph nodes }\end{array}$ & $\begin{array}{l}\text { Scintillation } \\
\text { counting and } \\
\text { autoradiography }\end{array}$ & 6 \\
\hline
\end{tabular}

\footnotetext{
${ }^{*} \mathrm{n}=$ normal mice; u.v. $=$ unilaterally vasectomized mice; $b . v .=$ bilaterally vasectomized mice;

$\mathrm{o}=$ oligozoospermic mice.

$\dagger$ DNA/protein fraction.

$\ddagger$ Spermatozoa isolated from tract and solubilized; lymph nodes solubilized.
}

programme and 5 pre-count standard samples. Two $0.5 \mathrm{ml}$ values were recorded. In Exps 2,3 and 4 the lymph nodes were identified by injecting $0.2 \mathrm{ml} 10 \%$ Evans Blue (Ball \& Setchell, 1983) into the footpads of 10 mice which were being killed for other purposes. In Exp. 2 the caudal lymph node, and pairs of iliac, renal and inguinal lymph nodes of each mouse were dissected out (Tilney, 1971), weighed and the radioactivity in the DNA/protein fraction was counted (see above).

In Exp. 3 the radioactivity in the DNA/protein fraction of only the caput epididymidis and caudal lymph nodes was counted. In Exp 4 spermatozoa were isolated from the caput, corpus and cauda and vas, and the complete reproductive tract of each mouse (normal, unilaterally vasectomized, bilaterally vasectomized and old ( 8 months) oligozoospermic mice) was removed and placed into PBS $\left(37^{\circ} \mathrm{C}\right.$, Dulbecco A). A known number of spermatozoa from each segment of the reproductive tract was dissolved in $3 \mathrm{~N}-\mathrm{KOH}$; this solution was then incubated at $50^{\circ} \mathrm{C}$ for $8-12 \mathrm{~h}$. After this period some samples were examined for fragments, $\mathrm{pH}$ was adjusted to neutral and $0.5 \mathrm{ml}$ was mixed with $9 \mathrm{ml}$ Fisofluor 1 scintillation cocktail. Spermatozoa, and not the DNA/protein fraction, were isolated because it was hoped that intrinsic sperm radioactivity in the tract could be correlated with the amount of radioactivity in the lymph nodes, presumably resulting from translocated spermatozoa. Half a caudal lymph node (other half for autoradiography), a pair of iliac lymph nodes and a pair of renal lymph nodes for each mouse were also solubilized in $3 \mathrm{~N}-\mathrm{KOH}$.

About 2000 autoradiographed, stained (haematoxylin and eosin or PAS) sections of half caudal lymph nodes were examined. Whole spermatozoa were sought microscopically under silver grain aggregates, using low-aperture or dark field illumination, for high contrast of grains combined with depth of focus, and phase-contrast or Nomarski interference-contrast microscopy. 
Expression of results. The counts reported have been corrected for background. The radioactivity in the reproductive tract was calculated as d.p.m. $\mathrm{mg}^{-1}$ and expressed as percentage d.p.m. $\mathrm{mg}^{-1}$ :

$$
\% \text { d.p.m. } \mathrm{mg}^{-1}=\frac{\text { (d.p.m. } \mathrm{mg}^{-1} \text { of sample) }}{\text { (total d.p.m./total weight of all reproductive tract samples on that side }} \times 100
$$

This takes into account: (i) the variability in the amount of label injected into the different testes; and (ii) variation in sample weight. Radioactivity in the lymph nodes of mice used in Exps 2 and 3 was expressed as d.p.m. $\mathrm{mg}^{-1}$. The results in the final experiment were expressed as d.p.m./1000 spermatozoa.

\section{Results}

Very little radioactivity was lost in the washings of the protein/DNA fractions; washings always had $<3 \cdot 3 \%$ the activity of the equivalent DNA/protein.

\section{Experiment 1}

The testes on the vasectomized and sham-operated sides had high counts before Day 26. Radioactivity appeared in the caput at Day 26 with noticeably more on Day 27 (Fig. 1). No labelled. spermatozoa were observed on the autoradiographs of sections of the caput before Day 26, but there were many labelled spermatozoa at Day 26, 26.5 and 27. Neither cauda nor vas showed significant radioactivity in these mice, and there were only unlabelled spermatozoa in the autoradiographs.

\section{Experiment 2}

The caput acquired radioactivity on Day 2 on the operated side and Day 3 on the shamoperated side (Fig. 2), and a maximum appeared in the corpus epididymidis on Day 5 (Fig. 2).

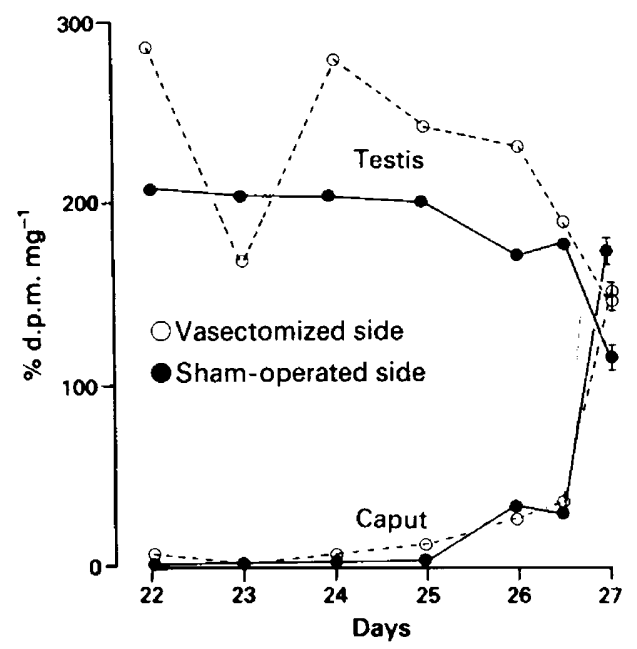

Fig. 1. Changes in radioactivity in the testis and caput epididymidis of unilaterally vasectomized mice after injection of $\left[{ }^{3} \mathrm{H}\right]$ thymidine into the testes (Exp. 1). One mouse at each time. 


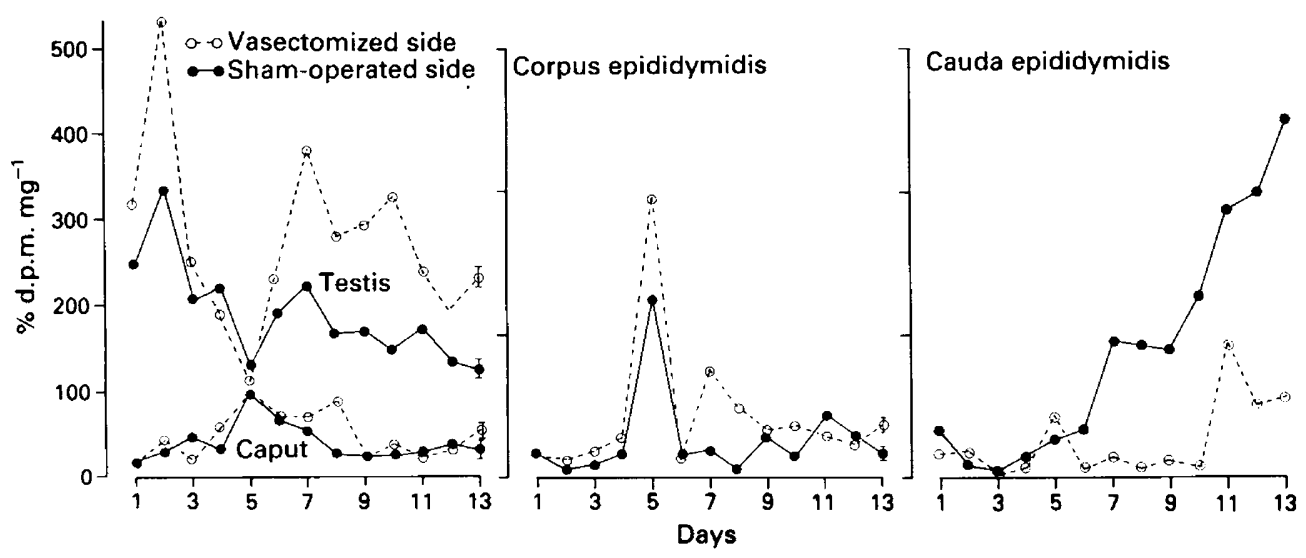

Fig. 2. Changes in radioactivity in the male reproductive tract of unilaterally vasectomized mice after injection of $\left[{ }^{3} \mathrm{H}\right]$ arginine into the testes (Exp. 2). One mouse at each time.

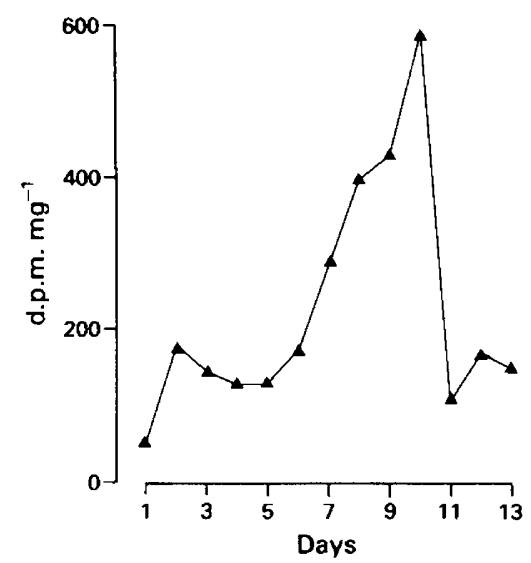

Fig. 3. Changes in radioactivity in the caudal lymph node of mice after injection of $\left[{ }^{3} \mathrm{H}\right]$ arginine into the testes (Exp. 2). One mouse at each time.

Similar levels were found on the sham and operated sides of each mouse, except possibly on Days 7 and 8 . The cauda epididymidis showed some differences between sham and operated sides (Fig. 2), with the vasectomized tracts showing a delay in the appearance of radioactivity on some 3-4 days. The vasa deferentia showed no significant radioactivity, in any of the mice, on either side up to 13 days. The caudal lymph nodes showed more radioactivity on each of Days 7-10 (Fig. 3); then, on Day 11 , there was noticeably less radioactivity than on Day 10 . The iliac nodes showed more radioactivity on Days 8-11 than on Days 3-5, as did the renal nodes, but there was much day-today variation. The inguinal nodes showed no rise above background levels on either side.

\section{Experiment 3}

In Exp. 3 the caudal lymph nodes of the unilaterally vasectomized mice again showed transient radioactivity (Fig. 4) which was also seen in oligozoospermic and even in one normal mouse: this was the normal Day 9 mouse, in which the caudal lymph node showed a high level of radioactivity. There was more radioactivity in the caudal lymph nodes of the unilaterally vasectomized than of oligozoospermic mice or normal mice. 


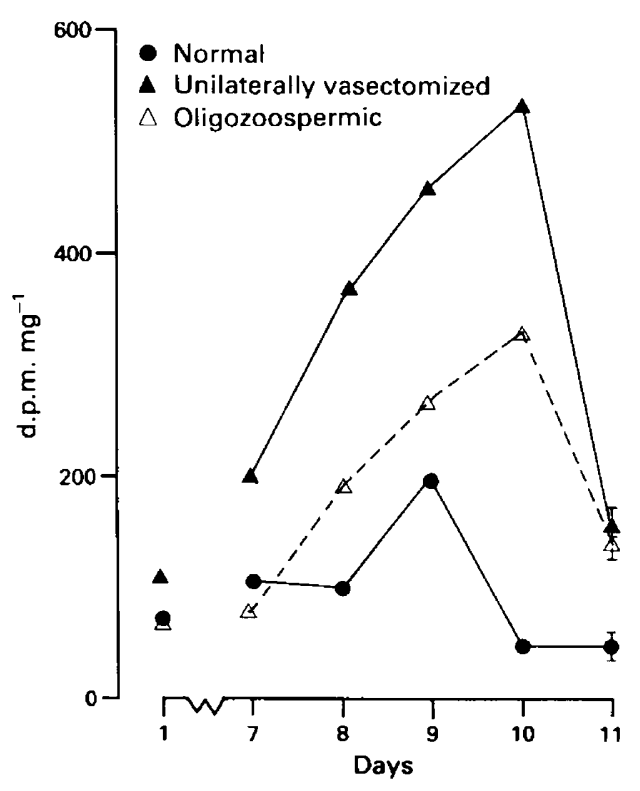

Fig. 4. Changes in radioactivity in the caudal lymph nodes of mice after injection of $\left[{ }^{3} \mathbf{H}\right]-$ arginine into the testes (Exp. 3). One mouse at each time.

\section{Experiment 4}

Spermatozoa in the caput epididymidis on the operated and the sham-operated side of unilaterally vasectomized mice at Day 27 showed considerable radioactivity (Fig. 5), as did those in the caput of normal and bilaterally vasectomized mice, at Days 26 and 27 . The corpus epididymidis of the sham and operated sides of unilaterally vasectomized mice and of normal and bilaterally vasectomized mice, all had fairly similar patterns of radioactivity. There was again a delay in the increase of radioactivity in the cauda on the operated sides of unilaterally vasectomized mice compared with the sham-operated sides (Fig. 5), and no mice showed radioactivity in the vas.

The (half) caudal lymph nodes of normal, unilaterally vasectomized and bilaterally vasectomized mice had a peak of radioactivity about Days 27-28 (Fig. 6). The iliac and renal lymph nodes of these mice showed a general increase in the levels of radioactivity after Days 26-27, but there was again much variation; the renal nodes of normal mice showed more radioactivity than did those of bilaterally vasectomized mice. In the caudal and iliac lymph nodes of the (old) oligozoospermic mice there was a general decrease in the level of radioactivity over this period, from the first measurement, at Day 24.

Many whole spermatozoa were seen in the tract smears and autoradiographs of normal or vasectomized mice, but very few whole spermatozoa were seen in the reproductive tracts of oligozoospermic mice, especially from the older males. No whole spermatozoa were observed in any of the autoradiographs of the caudal lymph nodes of any mice, but cells with a cluster of silver grains above them were seen in nodes of all categories of mice injected with the tritium label. Many more of these labelled cells were seen on the autoradiographs when scintillation counts were highest, and this was when labelled spermatozoa were found along the epididymis. Some cells, which could well be spermatids (stained with PAS), were observed in the caudal lymph nodes from oligozoospermic mice, but no silver grain concentrations were found over these. It was very difficult to recognize or to exclude sperm heads in sections of lymph nodes, even by use of a variety of optical techniques. 


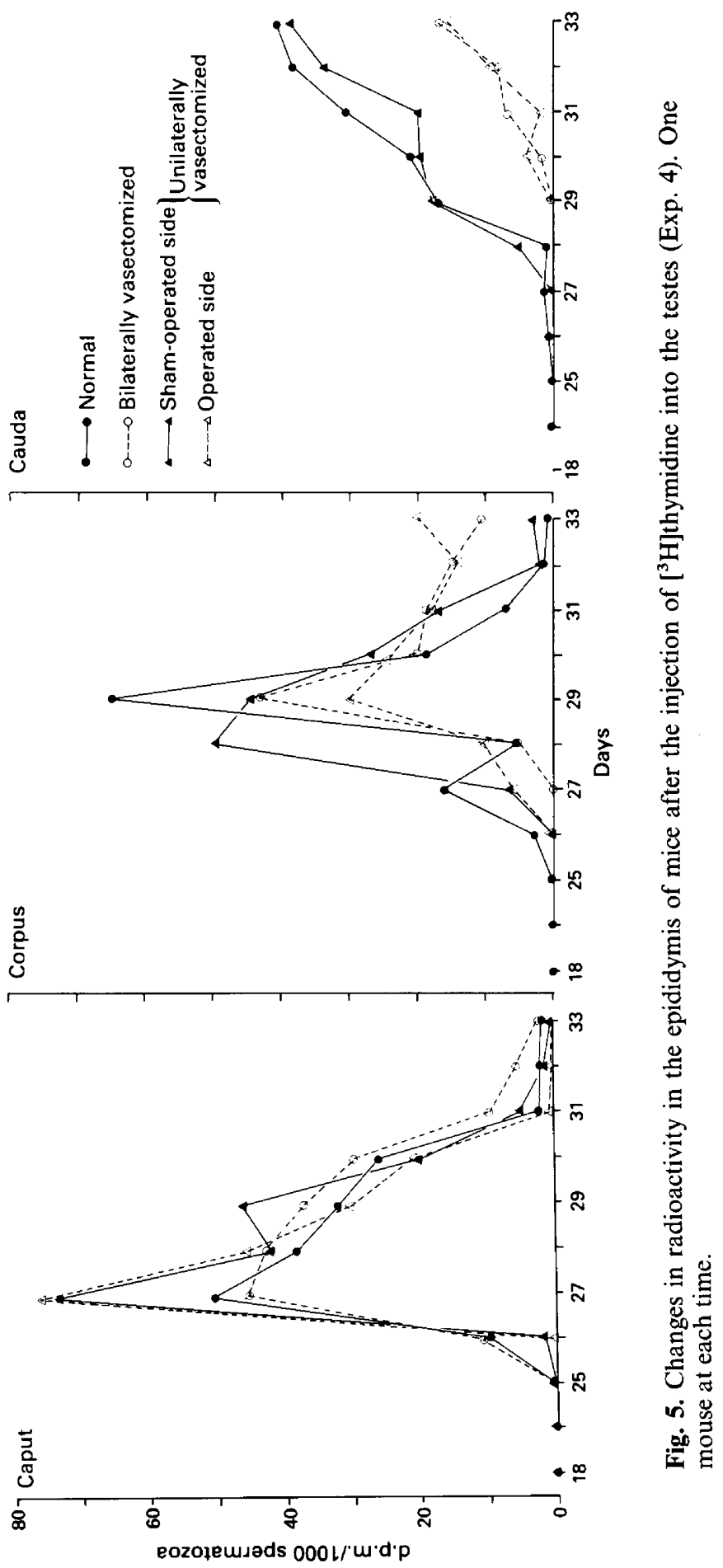




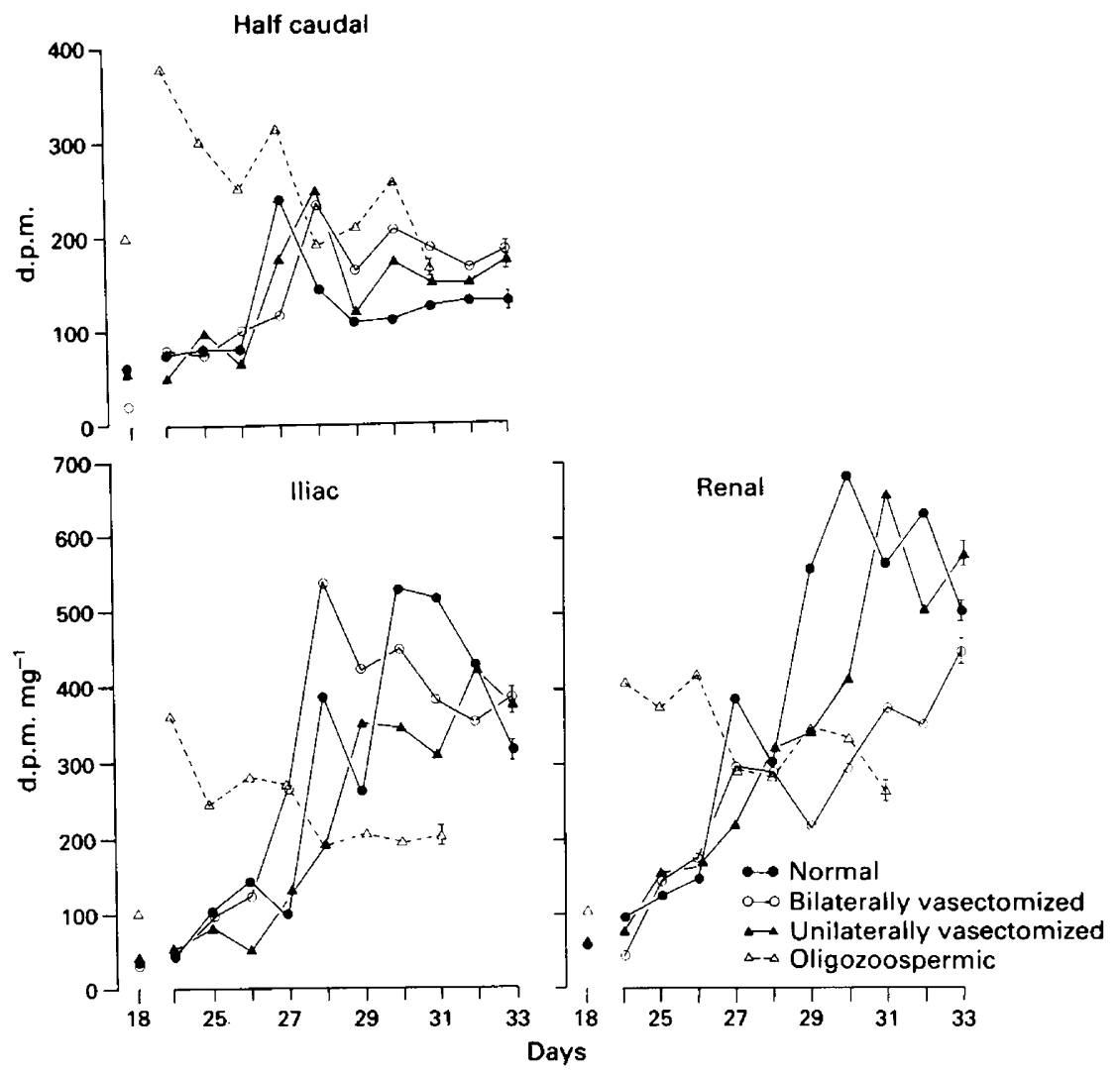

Fig. 6. Changes in radioactivity in the lymph nodes of mice after injection of $\left[{ }^{3} \mathrm{H}\right]$ thymidine into the testes (Exp. 4). One mouse at each time except at Days $32+$ Day 33 (no oligozoospermic mice).

\section{Discussion}

The results show clearly that labelled spermatozoa pass at about the same rate through normal and vasectomized mouse tracts down to the cauda, and that this ${ }^{3} \mathrm{H}$-label is translocated to the lymph nodes not only in vasectomized and oligozoospermic mice but also in normal mice.

Our minimal use of experimental animals was effective; it seems reasonable to assume that the succession of measurements does nearly always reflect the changing levels of radioactivity in the organs of an individual animal. By isolating the DNA/protein fraction, and washing off the free radioactivity in the process, we can be sure that the radioactivity being counted was in this fraction and was not small-molecule products of degradation.

The appearance of labelled spermatozoa on autoradiographs from the tracts correlated with raised scintillation counts from solubilized organs, thus confirming that these counts were detecting labelled spermatozoa. These results conflict with those of Tucker, Taylor, Siddiquey \& Cohen (1983) who showed 'spread' of $\left[{ }^{3} \mathrm{H}\right]$ arginine-labelled spermatozoa through several ejaculates. Our radioactivity was restricted to a small segment of the tracts, especially after $\left[{ }^{3} \mathrm{H}\right]$ thymidine labelling.

Sperm transport as far as the corpus epididymidis was unaffected by vasectomy, at least initially, as shown by scintillation and autoradiography with both labels. However, transport into the cauda epididymidis was delayed by about 3-4 days (Fig. 2; Fig. 5). Vasectomy therefore does 
not affect the rate of passage from the testes, because injected label appears in the caput at the expected (normal) time. It is not possible to determine directly whether testicular sperm production is affected, but other studies in progress show that daily sperm production rates are not affected at 6 weeks after vasectomy, although they are at 6 months after operation (data not presented). The present results show that transport as far as the cauda epididymidis is not greatly affected.

Radioactivity in the lymph nodes is likely to be from whole sperm heads, or at least largemolecule sperm products, because the radioactivity was in the DNA/protein fraction. Also, the pattern was similar when thymidine or arginine was used as tracer, and these do not share degradation or large-molecule breakdown pathways. That the radioactivity in nodes was due to spermatozoa and not to intrinsic uptake of the labels is shown by the low post-injection levels in the nodes, before labelled spermatozoa were in the tract. Radioactivity increased in these nodes only when labelled spermatozoa appeared in the tract, at about the time when they were in the corpus epididymidis. No whole sperm heads were identified unambiguously in the autoradiographs of the caudal node; this may have been due to the rapid dissolution of spermatozoa (Ball, Scott \& Mitchinson, 1984), or simply to the difficulty of identification. We therefore refer to radioactivity in the lymph nodes as spermatozoa/sperm products although it is possible that, as in the ram and boar, whole spermatozoa are translocated (Ball \& Setchell, 1983). Normal mice also showed the translocation very clearly, and so the disposal of spermatozoa/sperm products via the lymphatic system is not a special pathway brought into play after vasectomy, but occurs in normal mice and is further exploited after vasectomy (however, see Ball \& Setchell, 1983).

From the data for the amount of $\left[{ }^{3} \mathrm{H}\right]$ thymidine radioactivity per 1000 spermatozoa (Fig. 6) in the reproductive tract, and counts for the lymph nodes, an estimate of the proportion of sperm production that is diverted to the lymphatic system can be made. Firstly, we assume that thymidinelabelled spermatozoa are produced over a 3-day period and during this period about $4 \times 10^{6}$ spermatozoa are produced (and that the rate is the same for normal and vasectomized mice). From the mean d.p.m./1000 spermatozoa in the tract of each mouse on each day when labelled spermatozoa are present (Fig. 6), and the total sperm numbers in the tract segments, we can obtain figures for sperm radioactivity to be compared with radioactivity levels in the lymph nodes. We have calculated that, very approximately, $11 \%$ of the 3-day production is found in the nodes of normal mice, $12 \%$ in unilaterally vasectomized mice and about $15 \%$ in bilaterally vasectomized mice. We do not consider these figures to be more than order-of-magnitude estimates, but the internal consistency of our results justifies the arithmetic.

However, inconsistent results were obtained with the oligozoospermic mice. This is completely explicable by the difference in age of oligospermic males used in Exps 2 \& 3 (Hillman \& Nadijcka, 1980). In the older males in Exp. 4 fewer spermatozoa were found in the tract and more radioactivity in the lymph nodes, so perhaps more spermatozoa (and perhaps even spermatids) were being lost from the testis/tract into the lymph nodes; a higher degree of resorption in the testis of older males was also reported by Dooher, Berry, Artzt \& Bennett (1981). The earlier appearance of radioactivity in the caudal nodes of these mice might be due to such loss of spermatozoa/ radioactivity from the testes as well as the epididymides.

This normal physiological diversion of sperm products from the male tract into the lymph system is likely to stimulate immunological responses. After vasectomy, the production of autoantibodies to spermatozoa is said to be common and has been blamed for continued infertility after successful vasovasostomy (Plymate, Fariss \& Smith, 1983; Parslow, Royle, Kingscott, Wallace \& Hendry, 1983; Fuchs \& Alexander, 1983). However, the present results suggest that, because vasectomy exploits a physiological disposal mechanism, most vasectomies would not evoke such antibodies. Only in some small fraction would the normal immune mechanisms be overloaded so that pathology ensues. Perhaps attention to the anti-sperm antibody-producing mechanisms will elucidate the normal failure to respond to the continuous assault on the lymph nodes of men (and probably also of women) by the products of the dissolution of hundreds of millions of spermatozoa. 
We thank Mrs Linda Highfield for assistance in the typing of this manuscript and the SERC for financial support of C.L.R.B.

\section{References}

Ball, R.Y. \& Setchell, B.P. (1983) The passage of spermatozoa to regional lymph nodes in testicular lymph following vasectomy in rams and boars. $J$. Reprod. Fert. 68, 145-154.

Ball, R.Y., Naylor, C.P.E. \& Mitchinson, M.J. (1982) Spermatozoa in an abdominal lymph node after vasectomy in man. $J$. Reprod. Fert. 66, 715-716.

Ball, R.Y., Scott, N. \& Mitchinson, M.J. (1984) Further observations on spermiophagy by murine peritoneal macrophages in vitro. J. Reprod. Fert. 71, 221-116.

Bernard, R.T.F. (1984) The occurrence of spermiophagy under natural conditions in the cauda epididymidis of the Cape horseshoe bat (Rhinolophus capensis). $J$. Reprod. Fert. 71, 539-543.

Clermont, Y. \& Trott, M. (1969) Duration of the cycle of the seminiferous epithelium in the mouse and hamster determined by means of ${ }^{3} \mathrm{H}$ thymidine and autoradiography. Fert. Steril. 20, 805-817.

Cooper, T.G. \& Hamilton, D.W. (1977) Phagocytosis of spermatozoa in the terminal region and gland of the vas deferens of the rat. Am. J. Anat. 150, 247-268.

Dadoune, J.P. \& Alfonsi, M.F. (1984) Autoradiographic investigations of sperm transit through the male mouse genital tract after tritiated thymidine incorporation. Reprod. Nutr. Develop. 24, 927-935.

Dooher, G.B., Berry, R.J., Artzt, K. \& Bennett, D. (1981) A semi-lethal t-haplotype in the Orkney Islands. Genet. Res. 37, 221-226.

Flickinger, C.J. (1981) Focal changes in the seminiferous tubules of vasectomized hamsters. J. Androl. 5, 269-277.

Fuchs, E.F. \& Alexander, N.J. (1983) Immunologic considerations before and after vasovasostomy. Fert. Steril. 40, 497-500.

Fulka, J., Kopecny, V. \& Koefoed-Johnson, H.H. (1971) Tritium activity in spermatozoa and epididymal epithelium after the application of thymidine and passage blockage by ligature. Fert. Steril. 22, $119-124$.

Hillman, N. \& Nadijcka, M. (1980) Sterility in mutant $\left(t^{1 \mathrm{x}} / t^{1 y}\right)$ male mice. I. A morphological study of spermiogenesis. J. Embryol. exp. Morph. 59, 27-37.

Howards, S.S., Flickinger, C.J., Noller, D.W. \& Panko, W.B. (1979) Effects of vasectomy on testicular metabolism in the guinea pig. J. Reprod. Fert. 55, 401-405.
Jean, Y., Perrault, A., Auger, M., Roberts, K.D. \& Chapdelaine, A. \& Bleau, G. (1979) Properties of sperm in relation to their elimination after vasectomy. Archs Androl. 3, 139-146.

Johnson, L., Petty, C.S. \& Neaves, W.B. (1983) Further quantification of human spermatogenesis germ cell loss during post prophase of meiosis and its relationship to daily sperm production. Biol. Reprod. 29, 209-217.

Kopecny, V. \& Pavlok, A. (1975) Autoradiographic study of mouse spermatozoan arginine-rich nuclear protein in fertilization. J. exp. Zool. 191, 85-96.

Lepow, T.H. \& Crozier, R.H. (1979) Vasectomy: Immunologic and Pathophysiologic Effects in Animals and Man. Academic Press, London.

Lipshultz, L.I. \& Benson, G.S. (1980) Vasectomy: an anatomic, physiologic and surgical review. In Regulation of Male Fertility, pp. 169-186. Eds G. R. Cunningham, W. B. Schill \& E. S. E. Hafez. Martinus Nijhoff, The Hague.

Munro, H.N. \& Fleck, A. (1966) The determination of nucleic acids. In Methods of Biochemical Analysis, pp. 113-165. Ed. D. Glick. Inter-Sciences, New York.

Orgebin-Crist, M.C. (1965) Passage of spermatozoa labelled with thymidine through the ductus epididymis of the rabbit. J. Reprod. Fert. 10, 241-251.

Parslow, J.M., Royle, M.G., Kingscott, M.M.G., Wallace, D.M.A. \& Hendry, W.F. (1983) The effects of sperm antibodies on fertility after vasectomy reversal. Am. J. Reprod. Immunol. 32, 28-31.

Plymate, S.R., Fariss, B.L. \& Smith, W. (1983) Recovery of fertility following vasovasotomy. Andrologia 15, 279-281.

Rogers, A.W. (1979) Techniques of Autoradiography. Elsevier/North Holland, Amsterdam.

Tilney, N.L. (1971) Patterns of lymphatic drainage in the adult rat. J. Anat. 109, 353-369.

Tucker, M.J. (1980) Explanation of the sterility in $t^{x} / t^{y}$ male mice. Nature, Lond. 288, 367-368.

Tucker, M.J., Taylor, N.J., Siddiquey, A.K.S. \& Cohen, J. (1983) Transport of spermatozoa of known age in the female tracts of the rabbit and mouse, and their performance in vitro. In The Sperm Cell, pp. 38-42. Ed. J. André. Martinus Nijhoff, The Hague.

Received 19 September 1985 